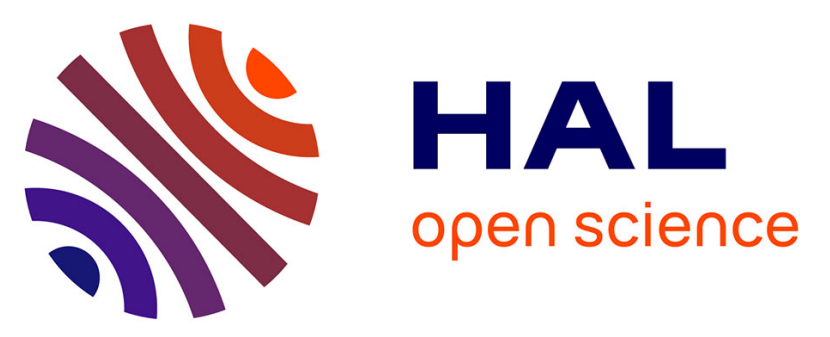

\title{
Near crater observations of gas and aerosols variability at Mount Etna during the EPL-RADIO and EPL-REFLECT measurement campaigns.
}

\author{
Suzanne Crumeyrolle, Marion Ranaivombola, Tjarda J Roberts, Chiara
} Giorio, Giusseppe Salerno, Salvatore Giammanco, Alessandro Laspina, Alcide Disarra, Letizia Spampinato, Pasquale Sellitto

\section{To cite this version:}

Suzanne Crumeyrolle, Marion Ranaivombola, Tjarda J Roberts, Chiara Giorio, Giusseppe Salerno, et al. Near crater observations of gas and aerosols variability at Mount Etna during the EPL-RADIO and EPL-REFLECT measurement campaigns.. vEGU21, 2021, Online, France. 10.5194/egusphereegu21-5684 . insu-03559376

\section{HAL Id: insu-03559376 \\ https://hal-insu.archives-ouvertes.fr/insu-03559376}

Submitted on 7 Feb 2022

HAL is a multi-disciplinary open access archive for the deposit and dissemination of scientific research documents, whether they are published or not. The documents may come from teaching and research institutions in France or abroad, or from public or private research centers.
L'archive ouverte pluridisciplinaire HAL, est destinée au dépôt et à la diffusion de documents scientifiques de niveau recherche, publiés ou non, émanant des établissements d'enseignement et de recherche français ou étrangers, des laboratoires publics ou privés. 


\section{EGU21-5684}

https://doi.org/10.5194/egusphere-egu21-5684

EGU General Assembly 2021

(c) Author(s) 2022. This work is distributed under

the Creative Commons Attribution 4.0 License.

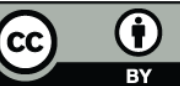

\section{Near crater observations of gas and aerosols variability at Mount Etna during the EPL-RADIO and EPL-REFLECT measurement campaigns.}

Suzanne Crumeyrolle ${ }^{1}$, Marion Ranaivombola ${ }^{1}$, Tjarda Roberts ${ }^{2}$, Chiara Giorio ${ }^{3}$, Giusseppe Salerno ${ }^{4}$, Salvatore Giammanco ${ }^{4}$, Alessandro Laspina ${ }^{4}$, Alcide Disarra ${ }^{5}$, Letizia Spampinato ${ }^{4}$, and Pasquale sellitto ${ }^{6}$

'University of Lille, Laboratoire d'optique atmosphérique, Villeneuve d'ascq, France (suzanne.crumeyrolle@univ-lille.fr) ${ }^{2}$ LPC2E-CNRS, Orléans, France

${ }^{3}$ Yusuf Hamied Department of Chemistry, University of Cambridge, Lensfield Road, Cambridge CB2 1EW, United Kingdom ${ }^{4}$ Instituto Nazionale di Geofisica e Vulcanologia, NGV-Osservatorio EtneoE, Sezione di Catania, Italy

${ }^{5}$ ENEA, Rome, Italy

${ }^{6}$ LISA-UPEC, Créteil, France

During the EPL (Etna Plume Lab) campaigns occurring in 2017 (EPL-RADIO) and 2019 (EPLREFLECT), gas and aerosol measurements were performed at Mount Etna (Sicily, Italy) to better assess the role of volcanic aerosols on both regional climate system and local health hazard. Gas related to volcanic emissions (such as $\mathrm{SO} 2, \mathrm{H} 2 \mathrm{~S}$ and others) were measured with low cost sensors (Alphasense) and $\mathrm{HCl} / \mathrm{SO} 2$ ratio was validated in comparison to FTIR measurements. Aerosol physical and chemical properties were measured using low-cost Optical Particle Counters (OPCN2 from Alphasense) and filter measurements dedicated to organic acids, inorganic ions, soluble metals and total metals. During the EPL-REFLECT campaign, in-situ measurements were performed during: 1) the hike up, 2) a 2-hours period in the close vicinity of the Bocca Nuova crater, 3 ) the hike down and 4) in Milo (city on the flank of the Etna). Moreover, few OPCs were left unattended at the Bocca Nuova crater for two full days.

Gas abundances at the crater-rim ranged from a few to 10's ppmv SO2, with correlation to PM. The analysis of the 2 days measurements highlights a clear diurnal variation of aerosol size distributions. Indeed, at sunrise the total number and mass concentration is rapidly increasing from $15 \mathrm{mg} / \mathrm{m} 3$ to $125 \mathrm{mg} / \mathrm{m} 3$ in less than 2 hours. The variation of PM1/PM10 ratio shows a constant trend throughout the day except during a short period of time associated with high wind speeds. These results suggest that most aerosols are emitted through degassing and conversion of precursor gases to particles.

Moreover, analysis of aerosol samples collected on filters showed a change in metal solubility from the samples collected at the crater and the samples collected after atmospheric transport in 
Milo. This may indicate that the volcanic plume underwent processing in the aqueous phase during transport. 